\title{
Effect of Silicon (Si) Application
}

on Phoenix dactylifera L. Growth under

Drought Stress Induced by

Polyethylene Glycol

(PEG) in Vitro

\author{
Ahmed Madi Waheed Al-Mayahi \\ Department of Plant Tissue Culture, Date Palm Research Centre, University of Basra, Basra, Iraq \\ Email: hng_1988@yahoo.com
}

How to cite this paper: Al-Mayahi, A.M.W (2016) Effect of Silicon (Si) Application on Phoenix dactylifera L. Growth under Drought Stress Induced by Polyethylene Glycol (PEG) in Vitro. American Journal of Plant Sciences, 7, 1711-1728.

http://dx.doi.org/10.4236/ajps.2016.713161

Received: August 1, 2016

Accepted: September 5, 2016

Published: September 8, 2016

Copyright ( 2016 by author and Scientific Research Publishing Inc. This work is licensed under the Creative Commons Attribution International License (CC BY 4.0).

http://creativecommons.org/licenses/by/4.0/

\begin{abstract}
This study was carried out to investigate the effects of silicon ( $\mathrm{Si}$ ) $3.6 \mathrm{mM}$ (as calcium silicate) under drought stress induced by polyethylene glycol "PEG" at 15\% (MW 8000 ), in addition to the control treatment on growth and some biochemical constituents of date palm cv. Barhee cultured in vitro. Drought stress (15\% PEG) depressed the growth of shoot and decreased protein content and chlorophyll concentration. Addition of $3.6 \mathrm{mM} \mathrm{Si}$ could improve the growth of shoot and increase the protein content and leaf chlorophyll concentrations of stressed plants. The inclusion of Si to the PEG containing medium significantly increased the catalase (CAT) and superoxide dismutase (SOD) activity in regenerated shoot, compared to other treatments. As well as drought stress 15\% PEG induced significant accumulation of shoots proline, which were decreased by added silicon. Moreover, the results were also supported by the observation that PEG stress-induced decrease the response percentage of root induction and root lengths was reversed by added silicon. Addition of Si obviously significantly increased the wax content in leaves, response percentage of root induction and root lengths of plantlets under drought stress. The results of this study indicate that the application of silicon improved growth attributes, effectively mitigate the adverse effect of drought, and increase tolerance of date palm plants for drought stress during the course of date palm tissue cultures.
\end{abstract}

\section{Keywords}

Silicon (Si), Drought Stress, Polyethylene Glycol (PEG), Tissue Culturing, Antioxidant Activity, Waxy Layer 


\section{Introduction}

Date palm (Phoenix dactylifera L.) $2 \mathrm{n}=36$ is a dioecious perennial monocotyledon fruit tree. It is believed to be a native of the Arabian Gulf region, possibly in Southern Iraq [1]. The increasing demand for date palms requires massive multiplication of selected plants. This could be achieved through tissue culture. Silicon ( $\mathrm{Si}$ ), as a macro-element, has a vital role in plants cycles. One of the main functions of $\mathrm{Si}$ is considered as one of the important beneficial nutrients for plant growth, especially when they are subjected to biotic or a biotic stresses [2]. Studies have shown that silicon application may increase tolerance to stresses especially salinity and drought in plants [3] [4]. The most widely reported mechanism was that Si might lead to osmotic adjustment and decrease the oxidative damage in plants subjected to stresses [5]. Drought is one of the most important environment stresses in agriculture, having several deleterious effects on plant growth and metabolic processes, including water relations and photosynthetic [6]-[8] suggested that "many of the changes observed under drought stress seem to represent general patterns of modulation in plants under adversity. Plant performance under stress conditions depends on the balance between the harmful effect of stress and a wide variety of protective and repair processes [9]. Polyethylene glycol (PEG), a non penetrated and non toxic osmotic lowers the water potential of the medium and has been used to stimulate water stress without harmful effects or toxic on the plant [10], but inhibits growth by lowering water potential of the medium [11] [12] stated that the adverse effects of PEG on plant growth were alleviated by adding $\mathrm{Si}$ to drought stressed treatments in terms of shoot length, shoot mass, root mass, and chlorophyll content. Si benefits to drought tolerance in wheat [13], maize [14], have been related to its effect on the antioxidant enzyme activities. Utilization of tissue culture techniques for quantifying stress tolerance of various crops has been increasing rapidly. Tissue culture techniques are useful for the evaluation of tolerance or adapt to different stresses because stress conditions can be easily controlled in vitro [15]. Also, in vitro cultures provide a uniform population of synchronously developing plant cells and thus, the results more accurate [16]. The simplicity of such manipulations enables the study of large plant population and stress treatments in a limited space and a short period of time as well. Simulation of drought stress under in vitro conditions during the regeneration process constitutes a convenient way to study the effects of drought on the morphogenic responses [17]. Studies have shown the beneficial effects of Si in plant tissue culture. Because silicon, actually, induces dehydration tolerance at tissue or cellular levels by improving the water status [18]. Yet, there is a limit of research on the effect of Si on drought stress in date palm plants. Therefore, the purpose of this study is to evaluate the effects of $\mathrm{Si}$ application under drought stress conditions induced by polyethylene gly$\mathrm{col}$ (PEG) can alleviate drought stress and improvement of plants growth of date palm cv. Barhee in vitro.

\section{Materials and Methods}

This work was conducted in the Tissue Culture Laboratory, Date Palm Research Cen- 
ter. Basra University, Iraq.

\subsection{Initiation Stage}

The apical meristems were divided longitudinally into four equal segments and cultured on medium composed of (MS) [19], with additional $30 \mathrm{mg} \cdot \mathrm{l}^{-1}$ Naphthalene acetic acid (NAA), $3 \mathrm{mg} \cdot \mathrm{l}^{-1}$ 2-isopentenyladenin (2iP) and $3 \mathrm{~g} \cdot \mathrm{l}^{-1}$ activated charcoal. The $\mathrm{pH}$ of the medium was adjusted to 5.8 with $0.1 \mathrm{~N} \mathrm{NaOH}$ or $\mathrm{HCl}$, before the addition of agar. Media were dispensed into culture test tubes. Subsequently autoclaved at $121^{\circ} \mathrm{C}$ and $1.04 \mathrm{~kg} / \mathrm{cm}^{2}$ for $15 \mathrm{~min}$. All cultures were incubated in a culture room under darkness at $27^{\circ} \mathrm{C} \pm 2{ }^{\circ} \mathrm{C}$ to initiate callus (Figure 1 ).

\subsubsection{Effect of Silicon (Si) and Polyethylene Glycol (PEG) on Adventitious Shoot Regeneration}

For induction and multiplication of shoots, callus were transferred into the shoot regeneration medium containing $3.6 \mathrm{mM}$ Si alone or in combination with $15 \%$ polyethylene glycol PEG (MW 8000), and were incubated at $27^{\circ} \mathrm{C} \pm 2{ }^{\circ} \mathrm{C}$ and $16 \mathrm{~h}$ photoperiod. Results of the experiments were evaluated 12 weeks after inoculation of callus in the regeneration medium. There were fifteen replicates of each treatment.

\subsubsection{Effect of Silicon on Rooting of Shoots under Drought Stress Induced by Polyethylene Glycol (PEG) in Vitro}

In another experiment, Micro propagated shoots of date palm $\mathrm{cv}$. Barhee with no visible signs of root development (Figure 2), were separated from each other and cultured on the rooting medium consisting of MS medium supplemented with $0.2 \mathrm{mg} \cdot \mathrm{l}^{-1} \mathrm{NAA}$ The media were supplemented with $3.6 \mathrm{mM} \mathrm{Si}$ as calcium silicate alone or in combination with $15 \%$ polyethylene glycol PEG (MW 8000). Test tubes containing Micropropagated shoots were incubated at $27^{\circ} \mathrm{C} \pm 2^{\circ} \mathrm{C}$ and $16 \mathrm{~h}$ photoperiod. Six weeks later root induction was measured by the percentage of roots and the length of roots regenerated per shoot. There were twelve replicates of each treatment.

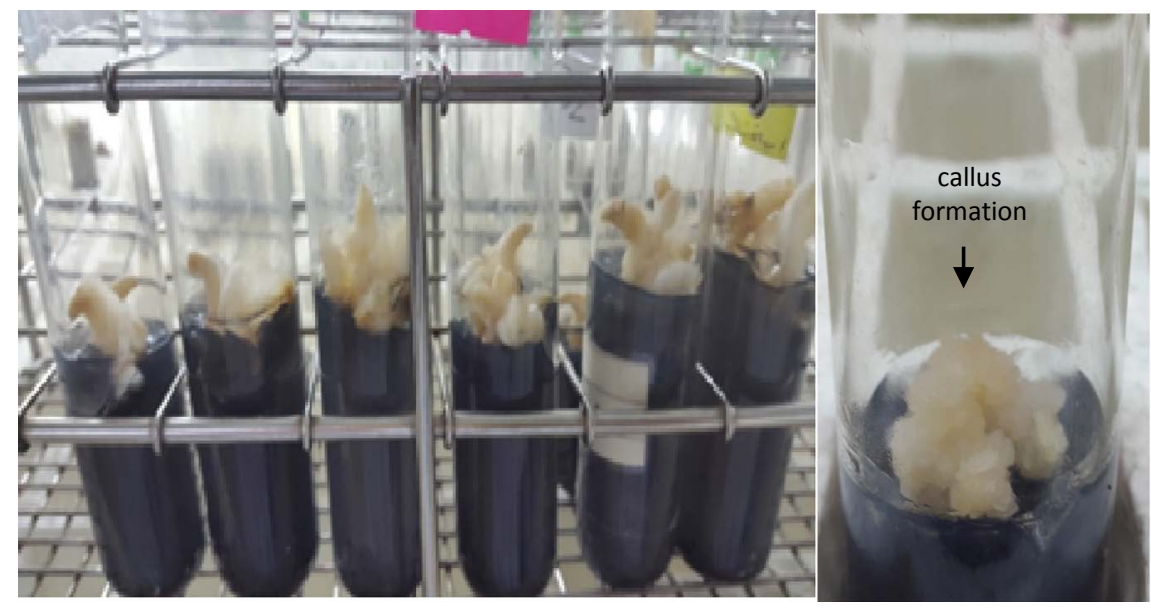

Figure 1. Culture of apical meristems in test tubes that containing "MS" medium and incubated under darkness at $27^{\circ} \mathrm{C} \pm 2{ }^{\circ} \mathrm{C}$, even the induction of callus. 


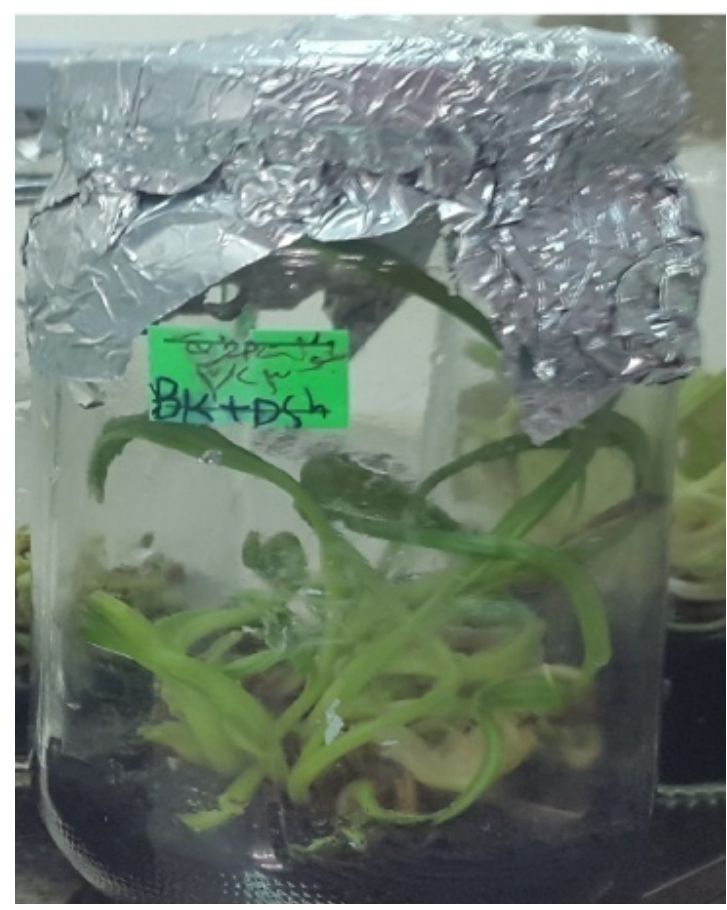

Figure 2. Micropropagated shoots will be separated from each other and cultured on the rooting medium.

\subsection{Biochemical Parameters}

\subsubsection{Enzyme Activities Assay}

Catalase activity (CAT) was assayed by following the decomposition of $\mathrm{H}_{2} \mathrm{O}_{2}$ at $240 \mathrm{~nm}$ [20]. The unit (U) of CAT activity was defined as the amount of enzyme that decomposed $1 \mathrm{mM} \mathrm{H} \mathrm{H}_{2} \mathrm{O}_{2}$ per minute per mg protein in $100 \mu \mathrm{l}$ enzyme extract are given in $\mathrm{U} / \mathrm{mg}$ of protein.

Superoxide dismutase (SOD) activity was determined by method of [21]. The reaction mixture contained $50 \mathrm{mM}$ potassium phosphate buffer $(\mathrm{pH} 7.0), 0.1 \mathrm{mM} \mathrm{Na}$ EDTA, $75 \mu \mathrm{M}$ riboflavin, $13 \mathrm{mM}$ methionine and $0.05 \mathrm{ml}$ the enzyme extract. One unit of SOD was defined as the amount of enzyme required to cause $50 \%$ inhibition of the reduction of nitro blue tetrazolium (NBT) as monitored at $560 \mathrm{~nm}$.

\subsubsection{Estimate the Free Proline Content}

Proline content of shoots was determined according to a modification of the method of [22]. Samples of shoots $(0.2 \mathrm{~g})$ were homogenized in a mortar and pestle with $3 \mathrm{ml}$ sulphosalicylic acid (3\%, w:v), and then centrifuged at $18000 \times \mathrm{g}$ for $15 \mathrm{~min} .2 \mathrm{ml}$ of the supernatant was then added to a test tube, to which $2 \mathrm{ml}$ glacial acetic acid and $2 \mathrm{ml}$ freshly prepared acid ninhydrin solution ( $1.25 \mathrm{~g}$ ninhydrin dissolved in $30 \mathrm{ml}$ glacial acetic acid and $20 \mathrm{ml} 6$ moll $^{-1}$ orthophosphoric acid) were added. The test tubes were incubated in a water bath for $1 \mathrm{~h}$ at $100^{\circ} \mathrm{C}$ and then allowed to cool to room temperature. $4 \mathrm{ml}$ of toluene was then added to the tubes and then mixed on a vortex mixer for $20 \mathrm{~s}$. The test tubes were allowed to stand for at least $10 \mathrm{~min}$, to allow separation of the toluene and aqueous phases. The toluene phase was carefully pipetted out into a glass 
test tube and its absorbance was measured at $520 \mathrm{~nm}$ in a spectrophotometer. The content of proline was calculated from a standard curve, and was expressed as $\mathrm{mg} \cdot \mathrm{g}^{-1} \mathrm{DW}$.

\subsubsection{Estimate the Total Soluble Proteins}

Proteins were extracted according to Method described by [23]. Fresh shoots material (250) $\mathrm{mg}$ was extracted with $2 \mathrm{~mL}$ of $0.25 \mathrm{M}$ Phosphate buffer PH7 and centrifuged for $3 \mathrm{~min}$ at $7000 \mathrm{~g}$. The supernatant was used as the crude Protein extract. The total proteins were measured by Spectrophotometer at $595 \mathrm{~nm}$ according to [24].

\subsubsection{Estimate the Amount of Chlorophyll in the Leaves of Date Palm cv. Barhee}

Take one gram of shoots date palm tissue (Plant inside the tubes). The extent in which the amount of chlorophyll by the method described by [25]. Where was added to the sample $50 \mathrm{~cm}^{3}$ acetone (80\%) and Grinded leaflets by mortar ceramic and returned extraction process that has become the sample colorless then taking part of the sample and placed in the centrifuge for $3 \mathrm{~min}$, then take a part of the solution pure and put in a device the Spectrophotometer type Apel PD303-UV and who was Adjust by acetone $80 \%$ and took reading the optical density at a wavelength of 645 and $665 \mathrm{~nm}$ and then estimated the total chlorophyll quantity of the sample according to the following equation: Total chlorophyll $\mathrm{mg} / \mathrm{liter}=20.2 \times$ optical density at a wavelength $645+8.02 \times$ optical density at a wavelength 665 conversion of the amount of chlorophyll mgl to 100 mg.

\subsubsection{Estimate the Amount of Wax in the Leaves of Date Palm cv. Barhee}

Wax were extracted according to method described by [26]. Leaflets material (1) gram was extracted with a mixture of acetone and ether petrolatum 2:1, the sample remains in the device for 24 hours and then is dried by rotary evaporator device and then weighed flasks, the difference between the two readings is the amount of wax in the leaves.

\subsection{Statistical Analysis: Statistical Analysis}

Analyses of variance (ANOVA) for all the variables were carried out using SAS analysis. Treatment means were compared using the protected least significant difference (LSD) test at $\mathrm{p}<0.05$ levels.

\section{Results and Discussion}

\subsection{Changes in Growth Parameters}

Results showed that addition of $3.6 \mathrm{mM}$ Si to the shoot induction medium significantly increased $(\mathrm{p}<0.05)$ both the response percentage of shoot induction and average number of shoots per jar. Si has been proven to be effective for shoot regeneration. The highest response percentage of shoot induction (73.34\%) with the average number of 9.2 shoots per jar was obtained on the shoot induction medium supplemented with 3.6 $\mathrm{mM}$ Si. The response percentage of shoot induction and average number of shoots re- 
generated per jar decreased on the medium containing 15\% PEG alone, while there was less decrease when the shoot induction medium was supplemented with both PEG and Si (Table 1, Figure 3).

Showed that drought-induced growth inhibition in date palm cv. Barhee in vitro was reversed by silicon supplementation in the media (Table 1) the reduction in shoot growth of drought stressed date palm might be due to the decline in cell enlargement and cell division.

Addition of $\mathrm{Si}$ to the shoot induction medium significantly increased both the response percentage of shoot induction and average number of shoots per jar.

Si has been proven to be effective for shoot regeneration in reed [27] and rice [28]. The highest response percentage of shoot induction (73.34\%) with the average number of 9.2 shoots per explant was obtained on the shoot induction medium supplemented with $3.6 \mathrm{mM}$ Si. In Ajuga multiflora, addition of Si to MS medium containing $2 \mathrm{iP}$ and IAA, enhanced adventitious shoot regeneration (about three-fold) [29]. [30] also reported that the use of calcium silicate at the rate of $60 \mathrm{mgl}^{-1}$ in the medium produced maximum green regenerated plants.

Si plays an important role in the defense response to different stresses as (salts, water, etc) in plant species [31] [32]. In most cases, silicon does not appear to be beneficial to plants until some stress is imposed [33]. Where, Si plays an important role under conditions of nutrient imbalance [34]. The Silicon ( $\mathrm{Si}$ ) is deposited in plant tissues and in cell wall apoplast to form silica and inhibiting stressor penetration and therefore which may cause tissue integrity [35]. The possible mechanisms responsible for better growth in the presence of Si under stressful conditions might be the prevention of loss of water from leaves of plant by keeping the water status maintained by the plant. Additionally the $(\mathrm{Si})$ appears to be involved in the fortification of plants against oxidation of cell membranes, leading to the protection of various plant structures and functions subjected to drought conditions, and therefore preventing stressor penetration. Silicon also appears to be part of the regulation of osmolytes within cells subjected to drought stress. That Si may act locally as a sign of the effects of natural defense responses by stimulating the activity of enzymes as SOD and CAT, can alleviate the effects of drought stress induced by $15 \%$ PEG in plants.

\subsection{Changes in Enzymatic Antioxidants}

Results showed that the activities of SOD and CAT were increased under drought stress induced by PEG (15\%), compared to control ( $\mathrm{p}<0.05)$. While inclusion of $\mathrm{Si}$ to the PEG containing medium significantly increased the SOD and CAT activities in shoots compared to the other treatments $(\mathrm{p}<0.05)$. Also, addition of Si caused increase of activities enzymes under normal condition (Table 2).

The amelioration of drought stress effects by Si addition, thus, silicon can increase the activity of antioxidant enzymes in plants and thereby detoxifies reactive oxygen species damage induced by drought stress. The desirable effect of Si on plants suffering from a biotic stresses often occurs during counteracting oxidative stress by modulating 
Table 1. Changes in response percentage of shoot induction and average number of shoots in date palm tissues after 12 weeks of treatments with $3.6 \mathrm{mM} \mathrm{Si}, 15 \%$ PEG.

\begin{tabular}{ccc}
\hline Treatments & $\begin{array}{c}\text { Response of callus }(100 \mathrm{mg}) \\
\text { for shoot formation }\end{array}$ & $\begin{array}{c}\text { Number of shoots/ } \\
\text { weight } 100 \mathrm{mg} \text { callus }\end{array}$ \\
\hline $\mathbf{0 . 0}$ & $60.0 \mathrm{~b}$ & $6.4 \pm 0.43 \mathrm{~b}$ \\
$\mathrm{Si}$ & $73.34 \mathrm{a}$ & $9.2 \pm 0.52 \mathrm{a}$ \\
PEG & $40.0 \mathrm{c}$ & $3.8 \pm 0.45 \mathrm{c}$ \\
$\mathrm{Si}+$ PEG & $53.34 \mathrm{~b}$ & $5.6 \pm 0.61 \mathrm{~b}$ \\
\hline
\end{tabular}

Data are means \pm SE $(n=15)$. Means followed by the different letter $(a, b, c$ and $d)$ in same column are significant different between the treatments at $p<0.05$ level of LSD.

Table 2. Changes in enzyme activities, catalase (CAT) and superoxide dismutase (SOD) in shoots of date palm after 12 weeks of treatments with $3.6 \mathrm{mM} \mathrm{Si}, 15 \%$ PEG.

\begin{tabular}{ccc}
\hline Treatments & CAT $\left(\mathrm{U} \mathrm{mg}^{-1} \mathrm{FW}\right)$ & SOD $\left(\mathrm{U} \mathrm{mg}^{-1} \mathrm{FW}\right)$ \\
\hline 0.0 & $12.48 \pm 0.22 \mathrm{~d}$ & $16.63 \pm 0.32 \mathrm{~d}$ \\
Si & $15.74 \pm 0.32 \mathrm{c}$ & $18.77 \pm 0.76 \mathrm{c}$ \\
PEG & $19.54 \pm 0.65 \mathrm{~b}$ & $24.73 \pm 0.45 \mathrm{~b}$ \\
Si + PEG & $23.66 \pm 0.25 \mathrm{a}$ & $28.25 \pm 0.55 \mathrm{a}$ \\
\hline
\end{tabular}

Data are means \pm SE $(n=3)$. Means followed by the different letter $(a, b, c$ and $d)$ in same column are significant different between the treatments at $\mathrm{p}<0.05$ level of LSD.

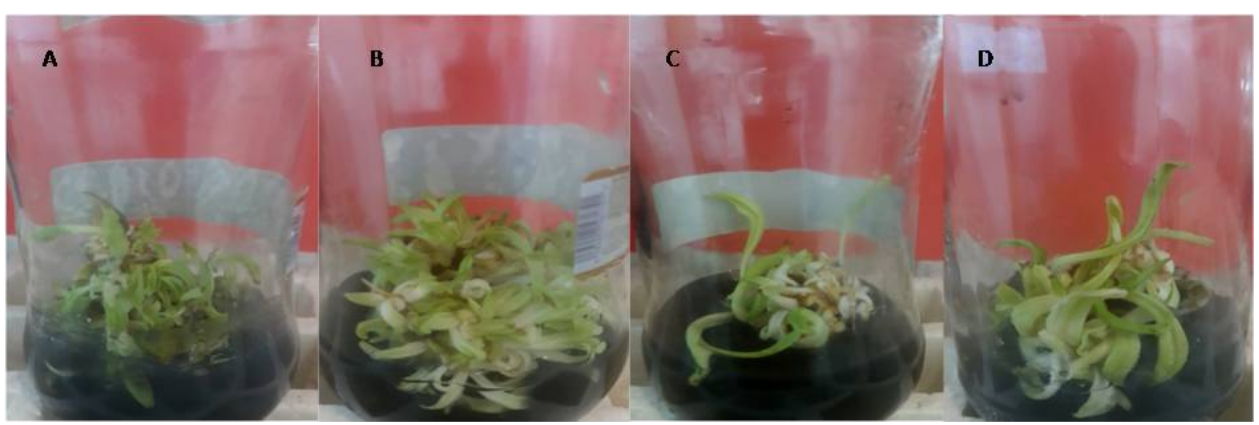

Figure 3. Shoots induction from callus cultured in MS medium (A) control (no additives) (B) 3.6 mM Si (C) 15\% PEG (D) 15\% PEG and $3.6 \mathrm{mM}$ si after 12 weeks from culturing.

antioxidant enzymes [3] [36] suggested that silicon induced stress tolerance in plants may be caused, at least in part, by increased antioxidant enzymes activity, which in turn decrease oxidative damage to membrane and enzyme activity Si treatment significantly affected the antioxidant enzyme activities in many plants [3] [29] [34]. Similarly, the activity of antioxidant enzymes increased during organogenesis in date palm [37] [38]. Thus, apparently Si promoted shoot regeneration of date palm by increasing activity of antioxidant enzymes.

In the present study, the activity of CAT and SOD in date palm cv. Barhee was increased in the shoots under drought stress induced by PEG at $15 \%$, while such an increase was more significant and consistent in $\mathrm{Si}$ treatment compared to other treat- 
ments. [39] catalase (CAT) is considered to be the most important enzyme that eliminates $\mathrm{H}_{2} \mathrm{O}_{2}$ which accumulate during different stresses and destroy the photosynthetic apparatus, also can be damage normal metabolism through oxidative damage of lipids, proteins and nucleic acids. According to [40], SOD and CAT are the most effective antioxidant enzymes in preventing cell destruction. These results are in agreement with the results of [12], who found out that under drought stress the addition of Si increased the antioxidant activity in wheat. As well as, [41] reported that the effect of Si on increase cellular membrane stability by the promotion of SOD activity because the malondialdehyde (MDA) concentration as an as a signal for lipid per oxidation was significantly lower in $\mathrm{Si}$ applied pistachio under stress condition, where caused not add silicon a significant increase of MDA and $\mathrm{H}_{2} \mathrm{O}_{2}$. Either CAT can eliminate $\mathrm{H}_{2} \mathrm{O}_{2}$ and play a key role in the elimination of $\mathrm{O}_{2}$. The combined effect of both antioxidant enzymes (CAT and SOD) is converts the toxic superoxide radical $\left(\mathrm{O}_{2}\right)$ and $\mathrm{H}_{2} \mathrm{O}_{2}$ to water and oxygen $\left(\mathrm{O}_{2}\right)$, and thus maintain the cells under drought conditions [42]. Also, the increase in SOD activity in shoots of drought stressed date palm might be due to the activation of preexisting SOD or due to synthesis of new SOD under drought stress. Changes in the activity of antioxidant enzymes, which are signals of plant adaption to stress conditions [43]. Variations in the antioxidant levels can serve as an indicator for the modification or modulating of reactive oxygen species scavenging mechanisms and ROSs signal transduction [44]. Increasing evidence shows that silicon treatment enhancing the activities of plant defensive enzymes [45].

\subsection{Changes in Proline}

Figure 4 shows that the shoot proline contents were significantly increased $(\mathrm{p}<0.05)$ under drought stress induced by PEG (15\%) compared to other treatments, while the addition of silicon $(\mathrm{Si})$ caused a decrease proline contents under drought stress. Further, under non-stress conditions, the addition of silicon ( $\mathrm{Si}$ ) increased the leaf proline content compared to the control but the differences between them are not significant $(\mathrm{p}<0.05)$.

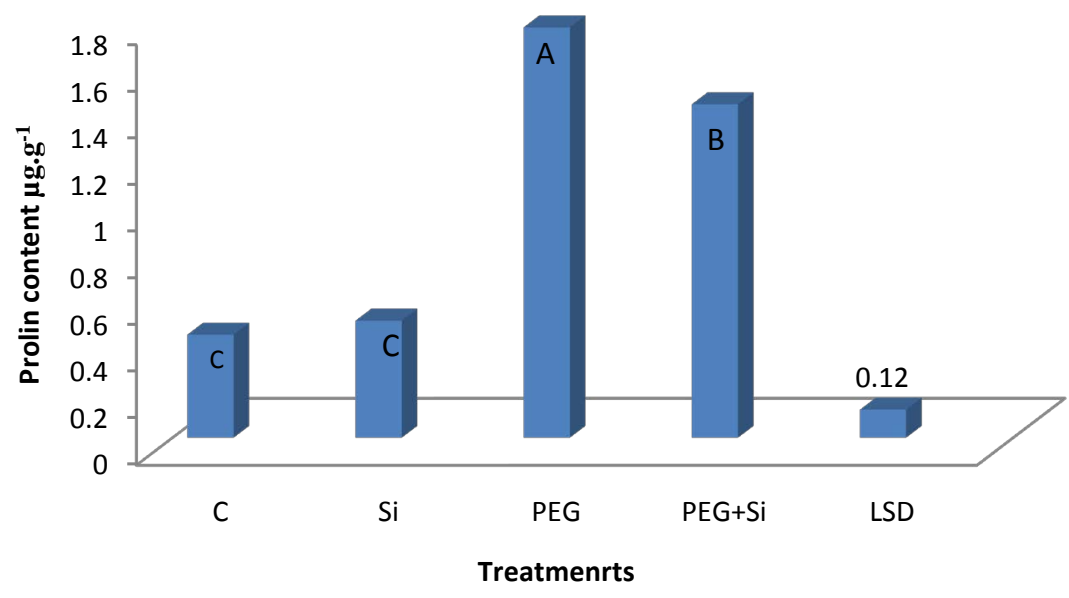

Figure 4. Free proline content in shoots of date palm under drought stress $(15 \%$ PEG) (with or without Si). C: control $(n=5)$. 
The mechanism of drought tolerance is by decreasing osmotic potential by increasing of solutes. Plants accumulate organic and inorganic solutes in the cytosol to raise osmotic pressure and thereby maintain both turgor and the driving gradient for water uptake [46]. Among these solutes, proline is an amino acid synthesized from glutamate or arginine under normal conditions, with the glutamate route being preferential during drought stress [47]. The synthesis of this amino acid has an important role in plants exposed to drought stress and has been considered to play a substantive role in osmotic adjustment [48]. Also, proline can act to modulate mitochondrial functions, which can be essential for plant recovery from stress [49]. On the other hand, Increasing PEG concentrations was also related with a progressive reduction in water content as well as with increased content of proline in callus of date palm [50]. In the current study, an increased proline concentration in the date palm shoot was observed under drought stress, while the addition of Si decreased its accumulation. Where the decrease in proline level in stressed plants upon silicon addition may reflect the alleviation of stress damage. The actual role of proline in osmotic tolerance remains controversial. Some researchers consider increased proline level as a symptom of damage rather than a cause for stress adaptation [51]. Since proline biosynthesis is a highly energy demanding process, and lower production the proline could benefit the plant by saving more energy for coping with stresses. [52] observed that proline concentration increases in wheat leaves under drought stress and that silicon addition decreases the proline accumulation. Generally, under stress condition, plants are working to adjust their proline increase to stabilizing sub-cellular structures such as membrane and proteins, scavenging free radicals and buffering cellular redox potential [53].

\subsection{Changes in Protein}

Figure 5 shows that the total soluble protein content were significantly decreased ( $\mathrm{p}<$ 0.05) under drought stress induced by PEG (15\%) compared to other treatments while the addition of silicon $(\mathrm{Si})$ caused an increase total soluble protein content under drought stress. Further, under non-stress conditions, the addition of silicon ( $\mathrm{Si}$ ) increased the total soluble protein content compared to the control.

The decrease in protein content in date palm shoots in vitro was found remarkable during drought stress induced by PEG at 15\%. The reduction in quantity of soluble proteins observed in present study can be related to the reduced rate of protein biosynthesis and increased breakdown of protein under stress conditions [54]. Similar results were observed by [13] in wheat. As reported by some researchers, protein degradation might be the result of increased activity of catabolic enzymes, such as protease which were activated under drought.

The alternation of protein synthesis or degradation is one of the fundamental metabolic processes that may affect the adjustment to the conditions of drought stress [55]. Plant growth under drought stress can also be affected by changes in gene expression, leading to the synthesis of novel proteins under drought stress conditions [56]. Further, addition of silicon to media increased soluble protein content of shoots, may be due to 


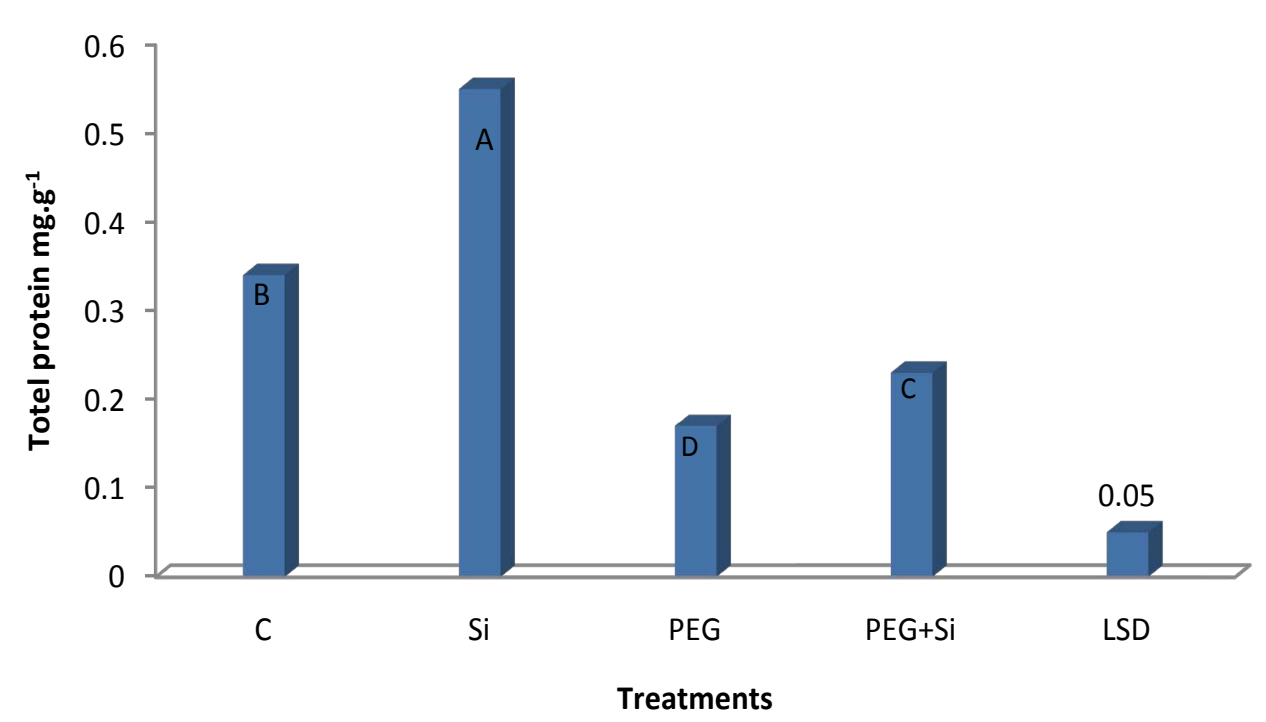

Figure 5. Protein content in shoots of date palm under drought stress (15\% PEG) (with or without $\mathrm{Si})$. C: control $(\mathrm{n}=5)$.

the Si has a role in binding amino acids to form certain proteins [57], additionally $\mathrm{Si}$ is actively involved information of DNA and functioning of mRNA [58].

\subsection{Changes in Root Growth}

In the present study, drought stress caused significant decreases in response percentage of root induction and the lengths of the roots of date palm plantlets cv. Barhee. While inclusion of Si to the PEG containing medium significantly increased the response percentage of root induction and root lengths compared with media containing PEG only. Further, under non-stress conditions, the addition of silicon (Si) improved these traits compared to the control but the differences between them are not significant $(\mathrm{p}<0.05)$.

In the present study, drought stress induced by PEG at $15 \%$ caused significant decreases in response percentage of root induction and root lengths of date palm cv. Barhee propagated in vitro. However, Si improved these traits only under drought stress conditions (Table 3). Some studies have shown that silicon addition can enhance root growth under drought conditions. In drought-stressed sorghum, [59] observed a higher formation for root to shoot ratio and higher root dry mass accumulation in silicon-applied plants compared with plants not treated with silicon, indicating that silicon facilitates root growth during drought stress [60]. Explained that silicon application is mainly beneficial to the growth of sorghum root under drought conditions. The simulative effect of silicon on root growth may be due to enhanced root elongation as a consequence of enhanced cell wall extensibility in the growth zone, as observed in sorghum [61]. The absorption of nutrients is related to root surface area and length [62]. An increase in surface area provides more exposed sites for uptake of diffusible ions [62]. Silicon-mediated enhancement of root growth may therefore encourage nutrient absorption and increase drought tolerance. 
Table 3. Changes in response percentage of root induction and average lengths of roots in date palm plantlets after six week of treatments with $3.6 \mathrm{mM} \mathrm{Si}, 15 \%$ PEG.

\begin{tabular}{ccc}
\hline Treatments & Rooting (\%) & Lengths of roots \\
\hline $\mathbf{0 . 0}$ & $75.00 \mathrm{a}$ & $4.7 \pm 0.25 \mathrm{a}$ \\
Si & $83.34 \mathrm{a}$ & $5.1 \pm 0.78 \mathrm{a}$ \\
PEG & $41.67 \mathrm{c}$ & $2.4 \pm 0.12 \mathrm{c}$ \\
Si + PEG & $53.34 \mathrm{~b}$ & $3.6 \pm 0.34 \mathrm{~b}$ \\
\hline
\end{tabular}

Data are means $\pm \mathrm{SE}(\mathrm{n}=12)$. Means followed by the same letterin same columnare not significant different between the treatments at $p<0.05$ level of LSD.

\subsection{Changes in Chlorophyll}

Results showed that drought stress induced by PEG (15\%) significantly decreased the pigment content $(\mathrm{p}<0.05)$ compared to other treatments (Table 4$)$, where the contents of chlorophyll a, b and total chlorophyll were decreased to $0.52,1,0.11$ and $0.62 \mathrm{mg} \cdot \mathrm{g}^{-1}$ FW respectively in drought stress conditions, while, addition of $3.6 \mathrm{mM}$ Si caused an increase in these contents under drought stress compared with the stressful treatment (without adding silicon) (Table 4).

Chlorophyll plays an important role in the photosynthesis and is responsible for assembling light. Decreases in photosynthetic pigments were due to instability of protein complexes and destruction of chlorophyll by increased activity of chlorophyll degrading enzymes and chlorophylls under high stress condition, as well as, enhanced oxidative stress that causes injury to chloroplast structure. Based on the [63], the reduction of chlorophyll due to stress is associated to the increase of production of reactive oxygen species (ROS) in the cells. These free radicals cause per oxidation, disintegration and reduction of chlorophyll content in plants under limited conditions. The content of photosynthetic pigments was significantly decreased by drought stress, which is in accordance with [64]. On the other hand, observed that application of Si increased the chlorophyll contents in wheat [13]. Some positive effects of Si application have been attributed preserving the percentage of water in leaves thus preventing destruction of photosynthetic process and chlorophyll in leaves [65]. Further, the deposition of silicon in the cell wall also increases tissue resistance and promotes better-performing plants due to leaf situation and their interception of light [66]. Correspondingly, a decrease was observed in the plants exposed to a water deficit in the absence of silicon, likely because of the decrease in nitrogen absorption, an essential element necessary for the produce or configure of chlorophyll. Silicon treatments were shown to cause changes to nitrogen metabolism [67]. Water is responsible for the conduction of nitrogen and other nutrients during their absorption through the root system. Thus, it can be concluded that in the present study, there was advancement in leaf combination with enhanced contents of chlorophyll, due to supplementation of silicates. The present study confirmed previous reports that the addition of Si could maintain the level of chlorophyll in capsicum (Capsicum annuum) under drought stress, suggesting that Si could alleviate drought stress-induced destroy in the photosynthetic systems and thus the improve- 
Table 4. Changes in chlorophyll a, b and total chlorophyll in date palm leaves after two month of treatments with $3.6 \mathrm{mM} \mathrm{Si}, 15 \%$ PEG.

\begin{tabular}{cccc}
\hline Treatments & $\mathrm{Chl} \mathrm{a}\left(\mathrm{mg} \cdot \mathrm{g}^{-1} \mathrm{FW}\right)$ & $\mathrm{Chl} \mathrm{b}\left(\mathrm{mg} \cdot \mathrm{g}^{-1} \mathrm{FW}\right)$ & Total Chl $\left(\mathrm{mg} \cdot \mathrm{g}^{-1} \mathrm{FW}\right)$ \\
\hline $\mathbf{0 . 0}$ & $0.91 \pm 0.04 \mathrm{a}$ & $0.22 \pm 0.005 \mathrm{a}$ & $1.13 \pm 0.046 \mathrm{a}$ \\
$\mathrm{Si}$ & $0.88 \pm 0.03 \mathrm{a}$ & $0.21 \pm 0.011 \mathrm{a}$ & $1.09 \pm 0.061 \mathrm{a}$ \\
PEG & $0.51 \pm 0.02 \mathrm{~b}$ & $0.11 \pm 0.002 \mathrm{~b}$ & $0.62 \pm 0.023 \mathrm{~b}$ \\
$\mathrm{Si}+$ PEG & $0.76 \pm 0.03 \mathrm{a}$ & $0.17 \pm 0.011 \mathrm{a}$ & $0.93 \pm 0.040 \mathrm{a}$ \\
\hline
\end{tabular}

Data are means \pm SE $(n=3)$. Means followed by the same letter in same column are not significant different between the treatments at $\mathrm{p}<0.05$ level of LSD.

ment of photosynthesis [68]. This result is in agreement with those reported by [14] [59] who found the significant Si-induced enhancement of chlorophyll concentrations under drought stress conditions in sorghum and maize plants respectively.

\subsection{Changes in the Amount of Wax}

Results showed that there are significant differences in the amount of wax in the leaves of plants cultured under different treatments. The amount of wax were increased under water stress induced by PEG $(15 \%)$, compared to control $(p<0.05)$. Also, addition of $3.6 \mathrm{mM}$ Sicaused increase of the amount of wax. While inclusion of $3.6 \mathrm{mM}$ Sito the PEG containing medium significantly increased the amount of wax in leaves compared to the other treatments $(\mathrm{p}<0.05)$ (Figure 6).

The silicon can induce beneficial changes in plants, such as the further development of tissues. Where, the addition of silicon as (calcium silicate) resulted in increased epicuticular wax deposition. The water loss of plants micropropated in vitro has been primarily attributed to a reduced deposition of epicuticular wax on the leaf surface. Also [69] suggested that the silicon was mainly deposited in the epidermis cells of the leaves and their cell walls. Poor growth of plants in drought stress conditions was significantly improved with Si application. Silicon potentially can induce anatomical changes in cell wall with deposition of silica in the form of polymerized silicon dioxide $\left(\mathrm{SiO}_{2}\right)$ solid particles, known as opalinephytoliths [34]. Various changes in the leaf structures of plants grown in vitro have been reported, Including the amount of wax deposited [70] [71]. It has been shown that silicon ( $\mathrm{Si}$ ) is associated with increased chlorophyll content and can lead to improvement on plant metabolism. This element also increased adaptation to stress, decreasing the imbalance of nutrients and toxic metals in the plant, strengthening the cell walls of plants and increasing the resistance against pathogens and pests [72]. The direct effects of silicon are accompanied by various indirect effects, such as, increases in the photosynthetic capacity, decrease rates of transpiratory, growth and development of plant and increased cellular mechanical resistance [73]. As reported [74], that the leaves of plantlets treated with $2 \%$ polyethylene glycol had the highest deposition of epicuticular wax, as compared with control. Which is reflected on the success of acclimatization. 


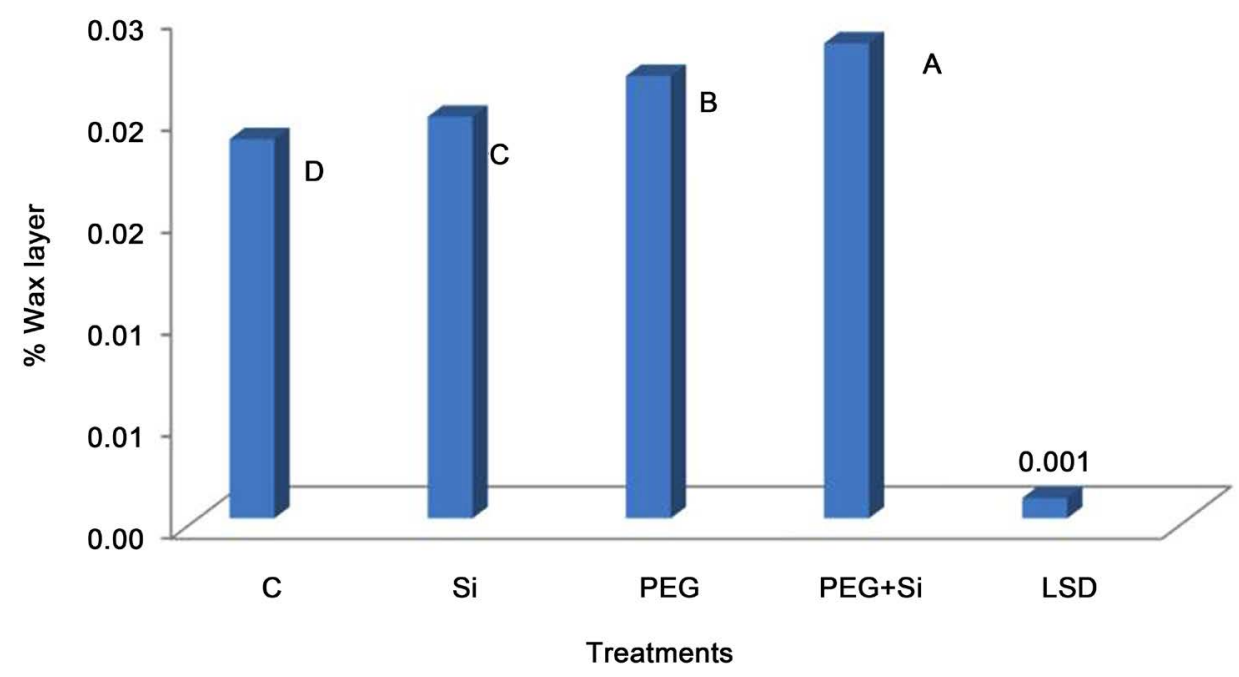

Figure 6. Wax content (\%) in leaves of date palm under drought stress (15\% PEG) (with or without $\mathrm{Si})$. C: control $(\mathrm{n}=5)$.

\section{Conclusion}

Our data show that the growth enhancement is an indication of positive effect of Si. Addition of $3.6 \mathrm{mM}$ Si to the PEG containing medium enhanced shoot regeneration and growth by altering activity of antioxidant enzymes in the plants to alleviate the oxidative damage leading to improvements in physiological attributes for the plants growth under drought conditions. Si may act to alleviate drought stress in date palm due to the increase of antioxidantive enzymes CAT and SOD. Si partially offsets the negative impacts of PEG stress due to increased the tolerance of date palm plantlets to PEG stress by enhancement of chlorophyll content and increase of the amount of wax. However, further studies are needed for a better understanding of the physiological or biochemical roles of silicon under stress in plants.

\section{References}

[1] Wrigley, G. (1995) Date Palm. In: Smart, J. and Simonds, N.W., Eds., Evolution of Crop Plants, 2nd Edition, Longman, London, 399-403.

[2] Sahebi, M., Hanafi, M.M., Akmar, A.S.N., Rafii, M.Y., Azizi, P., Tengoua, F.F., Azwa, J.N.M. and Shabanimofrad, M. (2015) Importance of Silicon and Mechanisms of Biosilica Formation in Plants. BioMed Research International, 16 p. http://dx.doi.org/10.1155/2015/396010

[3] Liang, Y.C., Sun, W.C., Zhu, Y.G. and Christie, P. (2007) Mechanisms of Silicon-Mediated Alleviation of Abiotic Stresses in Higher Plants: A Review. Environmental Pollution, 147, 422-428. http://dx.doi.org/10.1016/j.envpol.2006.06.008

[4] Bauer, P., Elbaum, R. and Weiss, I.M. (2011) Calcium and Silicon Mineralization in Land Plants: Transport, Structure and Function. Plant Science, 180, 746-756.

http://dx.doi.org/10.1016/j.plantsci.2011.01.019

[5] Saqib, M., Zorb, C. and Schubert, S. (2008) Silicon-Mediated Improvement in the Salt Resistance of Wheat (Triticum aestivum) Results from Increased Sodium Exclusion and Resistance to Oxidative Stress. Functional Plant Biology, 35, 633-639.

http://dx.doi.org/10.1071/FP08100 
[6] Cattivelli, L., Rizza, F., Badeck, F.W., Mazzucotelli, E., Mastrangelo, A.M., Francia, E., Marè, C., Tondellia, A. and Stanca, A.M. (2008) Drought Tolerance Improvement in Crop Plants: An Integrated View from Breeding to Genomics. Field Crops Research, 105, 1-14. http://dx.doi.org/10.1016/j.fcr.2007.07.004

[7] Xiong, J., Zhang, L., Fu, G.F., Yang, Y.J., Zhu, C. and Tao, L.X. (2012) Drought Induced Proline Accumulation Is Uninvolved with Increased Nitric Oxide, Which Alleviates Drought Stress by Decreasing Transpiration in Rice. Journal of Plant Research, 125, 155-164. http://dx.doi.org/10.1007/s10265-011-0417-y

[8] Hsiao, T.C. (1973) Plant Responses to Water Stress. Annual Review of Plant Physiology, 24, 519-570. http://dx.doi.org/10.1146/annurev.pp.24.060173.002511

[9] Caldwell, M., Bornmam, J., Ballare, C., Fint, S. and Kulandavelu, G. (2007) Terrestrial Ecosystems, Increased Solar Ultraviolet Radiation, and Interactions with Other Climate Changes Factors. Photochemistry and Photobiology, 6, 252-266. http://dx.doi.org/10.1039/b700019g

[10] Ober, E.S. and Sharp, R.E. (2003) Electrophysiological Responses of Maize Roots to Low Water Potentials: Relationship to Growth and ABA Accumulation. Journal of Experimental Botany, 54, 813-824.

[11] Matheka, J.M., Magiri, E., Rasha, A.O. and Machuka, J. (2008) In Vitro Selection and Characterization of Drought Tolerant Somaclones of Tropical Maize (Zea mays L.). Biotechnology, 7, 641-650. http://dx.doi.org/10.3923/biotech.2008.641.650

[12] Hamayun, M., Sohn, E.Y., Khan, S.A., Shinwari, Z.K., Khan, A.L. and Lee, I.J. (2010) Silicon Alleviates the Adverse Effects of Salinity and Drought Stress on Growth and Endogenous Plant Growth Hormones of Soybean (Glycine max L.). Pakistan Journal of Botany, 42, 1713-1722.

[13] Gong, H., Zhu, X., Chen, K., Wang, S. and Zhang, C. (2005) Silicon Alleviates Oxidative Damage of Wheat Plants in Pots under Drought. Plant Science, 169, 313-321. http://dx.doi.org/10.1016/j.plantsci.2005.02.023

[14] Li, Q.F., Ma, C.C. and Shang, Q.L. (2007) Effects of Silicon on Photosynthesis and Antioxidative Enzymes of Maize under Drought Stress. Chinese Journal of Applied Ecology, 18, 531-536.

[15] Errabii, T., Gandonou, C.B., Essalmani, H., Abrini, J., Idaomar, M. and Skali-Senhaji, N. (2006) Growth, Proline and Ion Accumulation in Sugarcane Callus Cultures under DroughtInduced Osmotic Stress and Its Subsequent Relief. African Journal of Biotechnology, 5, 1488-1493.

[16] Tal, M. (1983) Selection for Stress Tolerance. In: Evans, D.A., Sharp, W.R., Ammirato, P.V. and Yamada, Y., Eds., Hand Book of Plant Cell Culture, Volume 1: Techniques for Propagation and Breeding, McMillan, London.

[17] Sakthivelu, G., Akitha Devi, M.K., Giridhar, P., Rajasekaran, T., Ravishankar, G.A., Nedev, T., et al. (2008) Drought-Induced Alterations in Growth, Osmotic Potential and in Vitro Regeneration of Soybean Cultivars. General and Applied Plant Physiologyogy, 34, 103-112.

[18] Gao, X., Zou, C., Wang, L. and Zhang, F. (2006) Silicon Decreases Transpiration Rate and Conductance from Stornata of Maize Plants. Journal of Plant Nutrition, 29, 1637-1647. http://dx.doi.org/10.1080/01904160600851494

[19] Murashige, T. and Skoog F. (1962) A Revised Medium for Rapid Growth with Bioassays with Tobacco Cultures. Physiologia Plantarum, 15, 473-497. http://dx.doi.org/10.1111/j.1399-3054.1962.tb08052.x

[20] Dhindsa, R.S., Dhindsa, P. and Thorpe, A.T. (1981) Leaf Senescence Correlated with Increased Levels of Membrane Permeability and Lipid Peroxidation and Decrease Levels of 
Superoxide Dismutase and Catalase. Journal of Experimental Botany, 32, 93-101. http://dx.doi.org/10.1093/jxb/32.1.93

[21] Giannopolitis, C. and Ries, S. (1977) Superoxide Dismutase. I. Occurrence in Higher Plants. Plant Physiology, 59, 309-314. http://dx.doi.org/10.1104/pp.59.2.309

[22] Bates, L.S., Waldren, R.P. and Teare, I.D. (1973) Rapid Determination of Free Proline for Water Stress Studies. Plant and Soil, 39, 205-207. http://dx.doi.org/10.1007/BF00018060

[23] Lecouteux, C.G., Lai, F.M., Bryan, D. and Mckesie, B.D. (1993) Maturation of Alfalfa (Medicago sativa L.) Somatic Embryos by Abscisic Acid, Sucrose and Chilling Stress. Plant Science, 94, 207-213. http://dx.doi.org/10.1016/0168-9452(93)90021-Q

[24] Bradford, M.M. (1976) A Rapid and Sensitive Method for the Quantitation of Microgram Quantities of Protein Utilizing the Principle of Protein-Dye Binding. Analytical Biochemistry, 72, 248-254. http://dx.doi.org/10.1016/0003-2697(76)90527-3

[25] Abbas, M.F. and Abbas, M.G. (1992) Care and Storage of Fruits and Vegetables in Practice. University of Basrah, Basrah.

[26] AOAC (1984) Official Methods of Analysis. 14th Edition, Association of Official Analytical Chemists Inc., William, S., Ed., USA, 1141 p.

[27] Mathe, C., Mosolygo, A., Suranyi, G., Beke, A., Demeter, Z., Toth, V.R., et al. (2012) Genotype and Explants-Type Dependent Morphogenesis and Silicon Response of Common Reed (Phragmites australis) Tissue Cultures. Aquatic Botany, 97, 57-63. http://dx.doi.org/10.1016/j.aquabot.2011.11.005

[28] Islam, M.M., Ahmed, M. and Mahaldar, D. (2005) In Vitro Callus Induction and Plant Regeneration in Seed Explants of Rice (Oryza sativa L.). Research Journal of Agriculture and Biological Sciences, 1, 72-75.

[29] Sivanesan, I. and Jeong, B.R. (2014) Silicon Promotes Adventitious Shoot Regeneration and Enhances Salinity Tolerance of Ajuga multiflora Bunge by Altering Activity of Antioxidant Enzyme. The Scientific World Journal, 2014, Article ID: 521703. http://dx.doi.org/10.1155/2014/521703

[30] Wahed, S.A. (2003) Callus Induction and Plant Regeneration from Dehusked Rice Seeds. BSc Thesis, Agrotechnology Discipline Khulna University, Khulna, 24 pp.

[31] Ma, J.F. and Yamaji, N. (2006) Silicon Uptake and Accumulation in Higher Plants. Trends in Plant Sciences, 11, 392-397. http://dx.doi.org/10.1016/j.tplants.2006.06.007

[32] Sivanesan, I., Song, J.Y., Hwang, S.J. and Jeong, B.R. (2011) Micropropagation of Cotoneaster Wilsonii Nakai-A Rare Endemic Ornamental Plant. Plant Cell Tissue and Organ Culture, 105, 55-63. http://dx.doi.org/10.1007/s11240-010-9841-2

[33] Epstein, E. and Bloom, A.J. (2005) Mineral Nutrition of Plants: Principles and Perspectives. 2nd Edition, Sinauer Associates, Sunderland.

[34] Ma, J.F. (2004) Role of Silicon in Enhancing the Resistance of Plants to Biotic and a Biotic Stresses. Soil Science and Plant Nutrition, 50, 11-18. http://dx.doi.org/10.1080/00380768.2004.10408447

[35] Sang, G.K., Ki, W.K., Eun, W.P. and Doil, C. (2002) Silicon-Induced Cell Wall Fortification of Rice Leaves: A Possible Cellular Mechanism of Enhanced Host Resistance to Blast. Phytopathology, 92, 1095-1103. http://dx.doi.org/10.1094/PHYTO.2002.92.10.1095

[36] Zhu, Z.J., Wei, G.Q., Li, J., Qian, Q.Q. and Yu, J.Q. (2004) Silicon Alleviates Salt Stress and Increases Antioxidant Enzymes Activity in Leaves of Salt-Stressed Cucumber (Cucumis sativus L.) Plant Science, 167, 527-533. http://dx.doi.org/10.1016/j.plantsci.2004.04.020

[37] Al-Mayahi, A.M.W. (2014) Thidiazuron Induced in Vitro Bud Organogenesis of the Date Palm (Phoenix dactylifera L.) cv. Hillawi. African Journal of Biotechnology, 13, 3581-3590. 
http://dx.doi.org/10.5897/AJB2014.13762

[38] Al-Mayahi, A.M.W. (2016) Influence of Salicylic Acid (SA) and Ascorbic Acid (ASA) on in Vitro Propagation and Salt Tolerance in Date Palm (Phoenix dactylifera L.) cv. "Nersy". Australian Journal of Crop Science, 10, 969-976.

[39] Abdel Latef, A.H. (2011) Influence of Arbuscular Mycorrhizal Fungi and Copper on Growth, Accumulation of Osmolyte, Mineral Nutrition and Antioxidant Enzyme Activity of Pepper (Capsicum annum L.) Mycorrhizal, 21, 495-503. http://dx.doi.org/10.1007/s00572-010-0360-0

[40] Scandalios, J.G. (1993) Oxygen Stress and Superoxide Dismutase. Plant Physiology, 101, 7-12.

[41] Habibi, G. and Hajiboland, R. (2013) Alleviation of Drought Stress by Silicon Supplementation in Pistachio (Pistaciavera L.) Plants. Folia Horticulturae, 25, 21-29. http://dx.doi.org/10.2478/fhort-2013-0003

[42] Noctor, G., Veljvoic-Jovanovic, S. and Foyer, C.H. (2000) Peroxide Processing in Photosynthesis: Antioxidant Coupling and Redox Signalling. Philosophical Transactions of the Royal Society of London, 355, 1465-1475. http://dx.doi.org/10.1098/rstb.2000.0707

[43] Lee, D.H., Kim, Y.S. and Lee, C.B. (2001) The Inductive Responses of the Antioxidant Enzymes by Salt Stress in the Rice (Oryzasativa L.). Journal of Plant Physiology, 158, 737-745. http://dx.doi.org/10.1078/0176-1617-00174

[44] Mittler, R. (2002) Oxidative Stress, Antioxidants and Stress Tolerance. Trends in Plant Sciences, 7, 405-410. http://dx.doi.org/10.1016/S1360-1385(02)02312-9

[45] Rahman, A., Wallis, C. and Uddin, W. (2015) Silicon Induced Systemic Defense Responses in Perennial Ryegrass against Infection by Magnaporthe oryzae. Phytopathology, 105, 748757. http://dx.doi.org/10.1094/PHYTO-12-14-0378-R

[46] Rhodes, D. and Samara, Y. (1994) Genetics Control of Dsmoregulation in Plants. In: Strange, K., Eds., Cellular and Molecular Physiology of Cell Volume Regulation, CRC Press, Boca Raton, 347-361.

[47] Pulz, A.L. (2007) Water Stress and Silicon Fertilization in Popato (Solanum tuberosum L.) Cvbintje. MSc Thesis, Universidade Estadual Paulista, Brasil.

[48] Nayyar, H. and Walia, D.P. (2003) Water Stress Induced Proline Accumulation in Contrasting Wheat Genotypes as Affected by Calcium and Abscisic Acid. Plant Biology, 46, 275-279. http://dx.doi.org/10.1023/A:1022867030790

[49] Szabados, L. and Savoure, A. (2009) Proline: A Multifunctional Amino Acid. Trends in Plant Sciences, 15, 89-97. http://dx.doi.org/10.1016/j.tplants.2009.11.009

[50] Al-Khayri, J.M. and Al-Bahrany, A.M. (2004) Growth, Water Content, and Proline Accumulation in Drought-Stressed Callus of Date Palm. Biologia Plantarum, 48, 105-108. http://dx.doi.org/10.1023/B:BIOP.0000024283.74919.4c

[51] De-Lacerda, C.F., Cambraia, J., Oliva, M.A., Ruiz, H.A. and Prisco, J.T. (2003) Solute Accumulation and Distribution during Shoot and Leaf Development in Two Sorghum Genotypes under Salt Stress. Environmental and Experimental Botany, 49, 107-120. http://dx.doi.org/10.1016/S0098-8472(02)00064-3

[52] Pei, Z.F., Ming, D.F., Liu, D., Wan, G.L., Geng, X.X., Gong, H.J. and Zhou, W.J. (2010) Silicon Improves the Tolerance to Water-Deficit Stress Induced by Polyethylene Glycol in Wheat (Triticum aestivum L.) Seedling. Journal of Plant Growth Regulation, 29, 106-115. http://dx.doi.org/10.1007/s00344-009-9120-9

[53] Ashraf, M. and Foolad, M.R. (2007) Roles of Glycine Betaine and Proline in Improving Plant a Biotic Stress and Resistance. Environmental and Experimental Botany, 59, 206-216. 
http://dx.doi.org/10.1016/j.envexpbot.2005.12.006

[54] Ahmad, M.A., Murali, P.V. and Panneerselvam, R. (2013) Drought Stress Induced Biochemical Alterations in Two Varieties of Paspalum scrobiculatum L. International Journal of Current Science, 7, 80-96.

[55] Jiang, Y. and Huang, B. (2002) Protein Alternations in Tall Fescue in Response to Drought Stress and Abscisic Acid. Crop Science, 42, 202-207. http://dx.doi.org/10.2135/cropsci2002.0202

[56] Shinozaki, K. and Yamaguchi-Shinozaki, K. (1997) Gene Expression and Signal Transduction in Water-Stress Response. Plant Physiology, 115, 327-334. http://dx.doi.org/10.1104/pp.115.2.327

[57] Soundararajan, P., Sivanesan, I., Jana, S. and Jeong, B.R. (2014) Influence of Silicon Supplementation on the Growth and Tolerance to High Temperature in Salvia splendens. Horticulture, Environment, and Biotechnology, 55, 271-279. http://dx.doi.org/10.1007/s13580-014-0023-8

[58] Abbas, T., Balal, R.M., Shahid, M.A., Pervez, M.A., Ayyub, C.M., Aqueel, M.A. and Javaid, M.M. (2015) Silicon-Induced Alleviation of $\mathrm{NaCl}$ Toxicity in Okra (Abelmoschus esculentus) Is Associated with Enhanced Photosynthesis, Osmoprotectants and Antioxidant Metabolism. Acta Physiologia Plantarum, 37, 6. http://dx.doi.org/10.1007/s11738-014-1768-5

[59] Hattori, T., Inanaga, S., Araki, H., An, P., Morita, S., Luxova, M. and Lux, A. (2005) Application of Silicon Enhanced Drought Tolerance in Sorghum bicolor. Physiologia Plantarum, 123, 459-466. http://dx.doi.org/10.1111/j.1399-3054.2005.00481.x

[60] Ahmed, M., Hassen, F.U., Qadeer, U. and Aslam, M.A. (2011) Silicon Application and Drought Tolerance Mechanism of Sorghum. African Journal of Agricultural Research, 6, 594-607.

[61] Hattori, T., Inanaga, S., Tanimoto, E., Lux, A., Luxova, M. and Sugimoto, Y. (2003) Silicon-Induced Changes in Viscoelastic Properties of Sorghum Root Cell Walls. Plant and Cell Physiology, 44, 743-749. http://dx.doi.org/10.1093/pcp/pcg090

[62] Barber, S.A. (1984) Soil Nutrient Bioavailability: A Mechanistic Approach. Wiley Interscience, New York.

[63] Gill, S.S. and Tuteja, N. (2010) Reactive Oxygen Species and Antioxidant Machinery in Abiotic Stress Tolerance in Crop Plants. Plant Physiology and Biochemistry, 48, 909-930. http://dx.doi.org/10.1016/j.plaphy.2010.08.016

[64] Nahar, K., Hasanuzzaman, M., Mahabub-Alam, M. and Fujita, M. (2015) Glutathione-Induced Drought Stress Tolerance in Mung Bean: Coordinated Roles of the Antioxidant Defence and Methylglyoxal Detoxification Systems.

[65] Mali, M. and Aery, N.C. (2008) Silicon Effects on Nodule Growth, Dry-Matter Production, and Mineral Nutrition of Cowpea (Vigna unguiculata). Plant Nutrition and Soil Science, 171, 835-840. http://dx.doi.org/10.1002/jpln.200700362

[66] Lana, R.M.Q., Korndorfer, G.H., ZanãoJúnior, L.A., Silva, A.F. and Lana, A.M.Q. (2003) Effect of Calcium Silicate on the Productivity and Silicon Accumulation in the Tomato Plant. Bioscience Journal, 19, 15-20.

[67] Watanabe, S., Fujiwara, T., Yoneyama, T. and Hayashi, H. (2002) Effects of Silicon Nutrition on Metabolism and Translocation of Nutrients in Rice Plants. Developments in Plant and Soil Sciences, 92, 174-175.

[68] Lobato, A.K.S., Coimbra, G.K., Neto, M.A.M., Costa, R.C.L., Filho, B.G.S., Neto, C.F.O., Luz, L.M., Barreto, A.G.T., Pereira, B.W.F., Alves, G.A.R., Monteiro, B.S. and Marochio, C.A. (2009) Protective Action of Silicon on Water Relations and Photosynthetic Pigments 
in Pepper Plants Induced to Water Deficit. Research Journal of Biological Sciences, 4, 617623.

[69] Gribaudo, I., Novello, V. and Restagno, M. (2001) Improved Control of Water Loss from Micropropagated Grapevines (Vitis vinifera cv. Nebbiolo). Vitis, 40, 137-140.

[70] Khan, P.S.S.V., Kozai, T., Nguyen, Q.T., Kubota, C. and Dhawan, V. (2003) Growth and Water Relations of Paulownia fortunei under Photomixotrophic and Photoautotrophic Conditions. Biologia Plantarum, 46, 161-166. http://dx.doi.org/10.1023/A:1022844720795

[71] Hazarika, B.N. (2006) Morpho-Physiological Disorders in in Vitro Culture of Plants. Scientia Horticulturae, 108, 105-120. http://dx.doi.org/10.1016/j.scienta.2006.01.038

[72] Ahmed, M., Kamran, A., Asif, M., Qadeer, U., Ahmed, Z.I.,, Goyal, A. (2013) Silicon Priming: A Potential Source to Impart Abiotic Stress Tolerance in Wheat: A Review. Australian Journal of Crop Science, 7, 484-491.

[73] Asmar, S.A., Castro, E.M., Pasqual, M., Pereira, F.J.,, Soares, J.D.R. (2013) Changes in Leaf Anatomy and Photosynthesis of Micropropagated Banana Plantlets under Different Silicon Sources. Scientia Horticulturae, 161, 328-332. http://dx.doi.org/10.1016/j.scienta.2013.07.021

[74] Dami, I. and Hughes, H.G. (1997).Effects of PEG-Induced Water Stress on in Vitro Hardening of "Valiant" Grape. Plant Cell, Tissue and Organ Culture, 47, 97-101. http://dx.doi.org/10.1007/BF02318944

Submit or recommend next manuscript to SCIRP and we will provide best service for you:

Accepting pre-submission inquiries through Email, Facebook, LinkedIn, Twitter, etc. A wide selection of journals (inclusive of 9 subjects, more than 200 journals)

Providing 24-hour high-quality service

User-friendly online submission system

Fair and swift peer-review system

Efficient typesetting and proofreading procedure

Display of the result of downloads and visits, as well as the number of cited articles Maximum dissemination of your research work

Submit your manuscript at: http://papersubmission.scirp.org/ 